\title{
French erudités and the construction of Merovingian history
}

\author{
Dmitri Starostin \\ starostin.dmitry@gmail.com \\ Lecturer \\ Institute of History - University of St-Petersburg \\ 5, Mendeleevskaia Liniia \\ 199034 - St-Petersburg \\ Russia \\ Elena Kuleshova \\ kuleshova27@gmail.com \\ Lecturer \\ Institute of History - University of St-Petersburg \\ 5, Mendeleevskaia Liniia \\ 199034 - St-Petersburg \\ Russia
}

\begin{abstract}
This article addresses the ways in which scholars of history who worked in France in the 16th century attempted to describe and consider early medieval history and how in the course of this process they made slight adaptations to the image of the early medieval Frankish history that corresponded to the needs of the educated community and the emerging French monarchy. Thus, the article compares how the scholars Claude Fauchet, Bernards de Girarnd Sieur Du Haillan and others looked at the process of construction of the Frankish kingdom and how they addressed the relationship between the Mediterranean core of the Late Roman Empire and the diocese of Gaul which had long attracted the attention of the Franks, who became Roman soldiers and foederati. It is suggested that the bifurcation in historical knowledge took place in the 1570s in the works of Claude Fauchet and Bernard Du Haillan, one of which may still be ascribed to the earlier group of humanists who operated within the framework created by Leonardo Bruni and Flavio Biondo, whereas Bernard Du Haillan, on the other hand, sought to overcome the ideas and terms used by them and conceived of Frankish history in different terms. He emphasized the discontinuity between the Roman Empire and the Frankish Gaul, but at the same time sought to avoid the use of the discourse of national self-identification that permeated the works of earlier humanists.
\end{abstract}

\section{Keywords}

Intellectual history; Medieval History; History of France. 
Self-representations of European nations changed significantly when the later Middle Ages gave way to new society of the early Modern period despite a significant amount of continuity between the Later Middle Ages and the 16th century. The shifts in perception and the unique character of the modern view of the past were explained by a unique "régime de historicité", which appears within each chronologically-determined cultural system and which had changed significantly in the modern period in comparison to the Middle Ages (HARTOG 1993; HARTOG 2015, p. 15-20; 107-113). One may see the early modern "regime" as different from both medieval and modern, as one of a transition period, which, nevertheless, had its own peculiarities. It was the time when in the period between the Middle Ages and the Modern age a peculiar form of organization of knowledge, based around a "Republic of letters", was born and managed to survive for a historically short period of time (GRAFTON 2011, p. 13-14). Development of history as a discipline tremendously benefited from this process, but in the wake of nascent competition for priority in Europe by emerging monarchies of the early modern age it produced significant polemics between various strains of historical thought. Early medieval history became, as we will try to show, in addition to Roman history, one of the fields in which competition and tensions ran high as scholars from different parts of Europe sought to contribute to their own country's identity by envisioning the emerging medieval world from the perspective relevant to their own country's European ambitions.

In France, which will interest us as a country which produced its own strain of Renaissance historiography, the idea that a "new history" was in the making was shared in the end of the sixteenth century by authors like Jean Bodin and La Popelenier (HUPPERT 1970, p. 9; 23-27). This feeling among the educated historians has been interpreted in a number of ways, as that implying significant social repercussions of the new attitude to history, or as an indication of the discipline's conceptual and methodological characteristics. The new social role of historiography has been shown to express itself in a number of significant ways. But the question is whether the development of early modern history writing in France, North of the Alps, was in any way similar to the path it went in Italy, and whether the "republic of letters" was perceived in the field of historical knowledge. Much as in other disciplines, the intellectual community of scholars which enjoyed a free exchange of opinions in history and a polemic free of confessional or political restraints, barely managed to survive the 1550 s when the pressures from ecclesiastical and lay structures of authority began to mount (GRAFTON 2011, p. 13-14). In Italy, where the Renaissance history writing first appeared, it split by the 17 th century into three distinct types. In Florence public utility of writing about the past had disappeared by sheer attrition and it moved from piazza to the studio, thus becoming a purely learned pursuit. In Rome its utility was refashioned and history writing became a tool of Counter- Reformation, and in Venice it transformed into a new historiography that answered crucial problems of political and social existence (BOUWSMA 1990, p. 304-309). By the mid-17th century history-writing would also change in terms of approach, as the productive synthesis between rhetorical perfection, civic values and erudite 
knowledge of the past which had been achieved by the end of the 16th century would be split into two disparate strains: history as literature and history as research (COCHRANE 1981, p. 489). This happened in the 17 th-century France as "history reverted back to pleasant annals, while erudition turned into harmless antiquarianism" (HUPPERT 1970, p. 170-182). To make the matters worse, the synthetic approach, the use of which had been achieved by the early 17th century, fell in disfavor and almost disappeared from university and Jesuit schools' curricula, as they began to value literary aspects of historical treatises over those which sought to interpret the past by using a synthesis of rhetorical approach and erudite knowledge (BOUWSMA 1964-1965, p. 310; COCHRANE 1981, p. 489; FEINGOLD 1997, p. 329). And finally the interest to the ancients faded away and became more academic as the experience of New World conquest made the Ancient World resemble the savages and thus put a barrier, in fact, an ocean between them ("entre les Anciens et nous, il finira par yavoir un ocean") (HARTOG 2005, p. 38). Thus in the relatively short period of time between the 1500 and 1650 the development of history writing went full circle as it reached its peak by 1600 , at least as viewed by its contemporaries, and then lost much of its synthetic quality by the middle of the 17th century. The modernity with its fervent interest to the present gradually took its hold (HARTOG 2015, p. 107-113).

But was there a period in history writing in the 16th century, the achievements of which were more durable and which may still be employed to support the idea of continuity of historical thinking throughout the early modern period and to find elements of concepts and method that united, rather than divided historians of the early modern and modern period? Moreover, what model is applicable to France, given the different structure of power in which the monarchy had long occupied a central place in the politics? It has been established that history writing became in France a learned exercise for layers and jurists who made it into a sign of their intellectual and even social identity and a corollary to their profession (KELLEY 1970). History thus became part of knowledge espoused by those who considered themselves belonging to "republic of letters" (GRAFTON 2011 , p. 9). Looking at the same process from the standpoint of emerging and quickly transforming early modern monarchies (LE ROY LADURIE 1987, see part III; ELLIOTT 1992). scholars noted how writing of history became a means of furthering the construction and buttressing of monarchy, as historians were "charged" with the task of describing and confirming the monarchy's success (GRELL 1998, p. 538). The problem of power balance between the Empire, held by Charles $\mathrm{V}$ and Philip II, and the kingdoms which naturally felt themselves sidelined caused history, and especially that of the late Roman Empire and of the early medieval kingdoms, to become one of the politically charged themes (GRELL 2011). Thus already in the 16th century a process had begun which in the 17 th century would cause history to become an instrument of apologetic commentaries and justification of monarchy (GRELL 2007). But development of history writing in France may warrant more attention as there had obviously been undercurrents of historical thought that disappeared from wide usage 
and as there are still many problems of interpreting the approaches taken by scholars of history.

In this study we would like to address French history writing from a perspective of its approach to the emergence of the early medieval kingdom of Franks and its assessment in terms of relationship to Roman Empire's heritage. This is especially interesting because few specialists in early medieval history ever addressed 16th-century historical treatises from a purely medievalist's standpoint as they are considered fairly outdated in terms of their academic value. However, they are important as treatises that provide a look at the concepts of past that were created in struggles for France's image in Europe. Representations of early medieval history and their transformation over the early modern period occupy a very important place in this context because for the intellectuals and their royal sponsors in Europe North of the Alps this period became key to producing a new early modern self-identification for the emerging early modern monarchy in the period of "Bourbon spring" (LE ROY LADURIE 1987, Part III). The ways in which early medieval themes were re-interpreted by French historians who led a search of the kingdom's identity in the context of new European intellectual climate is the purpose of this investigation. Historical works on the Frankish kingdom laid the foundation for this period's study and made it into a significant historical field. Scholars like Étienne Pasquier (1529-1615), Bernard de Girard Sieur Du Haillan (1535-1610), Claude Fauchet (1530-1602). were those who laid the foundation of the France's early medieval history that allowed Bodin and La 80 Popelenier to produce their synthetic and conceptual visions of history in general (PASQUIER 1560; DU HAILLAN 1570; DU HAILLAN 1576b; DU HAILLAN 1576a; FAUCHET 1579). The period of the 1560-1580 was especially productive for this kind of studies as the new intellectual climate let scholars produce works on early medieval, Frankish history which combined both rhetorical perfection and erudite content. This is the period to which we would like to pay attention in this study, since a number of interesting treatises appeared in this period which may help illustrate the key aspects of the shift towards new meaning of early Frankish history and new forms of historical investigation.

One of the ways in which modern scholars sought to capture and define this change was addressing the formal methodology of the historical inquiry. Thus it is obvious, for example, that a significant transformation took place in perceiving and writing about the past between the first attempts to approach history in light of the new sources on Classical and medieval periods, associated with the names of Leonardo Bruni, Flavio Biondo and a few others, and the approaches of scholars of the 18th century like Du Tillemont whose Roman history became a foundation for modern Classical scholarship and inspired Gibbon in his studies. The French scholar's investigation, although produced within the dominant historical paradigm of the moment and thus addressing the history of emperors and the history of church in two separate treatises, were a breakthrough in their own period because they sought in the first place to establish critical facts of Roman history regardless of the ecclesiastical affiliation of its author, to provide critical review of all available sources (LE NAIN DE 
TILLEMONT 1701; LE NAIN DE TILLEMONT 1720; BREISACH 2008, p. 194-195). Thus it was noticed that only in the third quarter of the 16th century historical studies began to turn into "investigations" and away from the formerly used adaptation of Classical, and partly rhetorical, discourse (BOUTEILLER 1945, p. 357). Many, if not all of the techniques modern historians use in their work in collecting piecemeal evidence appeared in the Renaissance (FINDLEN 2002, p. 116). In this period scholars contributed to the transformation of history writing from a chronicle with purely chronological structure to a treatise which was structured events and thus provided an interpretation (COCHRANE 1981, p. 295-315). More importantly, it was in the second half of the 16th century that scholars came to understand that history cannot be reconstructed by using just one narrative, but needs to be reconstructed and collected from all available sources (FINDLEN 2002, p. 116; GRAFTON 2007, p. 68). At the same time, the Renaissance art of history produced the basic chronological structure that we still use today, and created the notion of "Medieval" history that up to know serves as a source for investigating the construction of Europe's identity in the aftermath of the Western Empire's collapse (BRUNI 2001, p. 88; 89; FINDLEN 2002, p. 116; CONNELL 2012, p. 352). This coincided with and in some ways was the cause of rethinking of the role of early medieval Frankish kingdom for the history of Europe in general, and of its claim to be an heir of the Roman Empire. Which of these models of interpreting early modern historical treatises work for a specialist in early medieval history if he addresses the treatment of early medieval Frankish kingdom in these treatises?

To understand and better perceive the challenges which the French historians faced when writing on the creation of the Frankish kingdom one may need to examine first the idealized picture of Roman history which came to dominate early modern history writing and which greatly influenced the ways in which French scholars created their own vision of medieval history. Leonardo Bruni from Arezzo, one-time Chancellor of the Florentine republic, exemplified how historians could use the ideal constructed representations of the political and civic culture of Antique polis and rhetorical and narrative structures and strategies of the Classical authors like Thucydides in describing medieval history of Florence. His Florentine history greatly influenced Humanistic historians (IANZITI 2012, p. 7). His treatise carried almost no new factual information because it was based on the histories of this city written hitherto. Bruni used "the classical topoi to establish the coordinates of the positions of protagonists in the stream of historical events" (STRUEVER 1970, p. 138). Thus history's presentation underwent significant transformations because "the gap between theory and practice, between intellect and will was to be bridged by speech." (VICKERS 1981, p. 128; MACK 2011, p. 311-315). Rhetorical practices became a part of the discipline's official presentation, but they also led to interiorization of discourse and to production of the more personal, if not psychologizing approach to described events (PÉCORA 2001, p. 79-116; HANSEN 2012, p. 159-161). In history this acquired a peculiar strand because it meant using the rules of rhetoric and hence, reason, in an attempt to establish the author's own 
interpretation of events against succumbing to chronicle tradition. Bruni sought to give a new touch to Florence's past because he insisted that this city had been established no later than Caesar and Octavian Augustus created Roman Empire. Thus Leonardo Bruni argued for republican roots of Florentine history and set the past of this city apart from both certain tyrannical aspects in Roman history and from the medieval history of other Italian cities, at the same time trying to represent its political organization and standing as unique (CONNELL 2012, p. 352; CABRINI 2010, p. 130; IANZITI 2012, p. 117-147, 204-236). It has been argued that this argument had less to do with nascent historical criticism that with the interpretation of the scholar of Roman and medieval history and hence of present-day events in Europe (IANZITI 2007, p. 253-257). Bruni also pioneered the division of history into three periods that established a dichotomy of the Antique Mediterranean South with its civic values and polis organization and the barbarian North which caused the destruction of the Classical world and contributed to its replacement by medieval barbarian kingdoms. His division consisted of the Classical, Medieval and Modern periods and he thus put the Middle Ages on the map (BRUNI 2001, p. XVII; 88-89; CONNELL 2012, p. 351). This periodization suggests that he saw the Middle Ages as lacking in Roman imperial legitimacy. In his narrative barbarians overtook Rome and thus the cause of the Roman downfall was external rather than internal. Odovacer, who displaced the last Roman emperor, was for him, paradoxically, no other than a tyrant ("Gothi Theoderico duce invadere Italiam statuerunt iam pridem afflictam 82 variis barbarorum incursionibus et tunc Odoacri tyrannide occupatam") (BRUNI 1441 , p. 3). The attacks of Theoderic the Great and his rule, although being the same in quality as those of Odovacer, received a welcome response from Bruni although it is difficult to see the difference between the two barbarian rulers. The acceptance of Theodoric by the Roman aristocracy, his title of a patricius, his Edict that was to make him resemble Roman emperors made him a more acceptable ruler in terms of Roman tradition (BRUNI 1441, p. 4). Thus Bruni created an imagined ideal of Romanness which was different from actual, imperial Rome, and made a distinction between different barbarian rulers, seeing acceptance by some of them of Roman traditions as a sign of positive development within society of barbarians (BRUNI 1441, p. 4). His vision his was meant to emphasize the primacy of the Mediterranean and, particularly, Italian culture as an heir to the Roman Empire in the long-standing competition and conflict with the Holy Roman Empire of the Middle Ages.

This approach had an enormous effect on the writing of history in early modern Europe as proving continuity and importance of Roman heritage became one of the utmost goals of Humanists from Spain. The two best-known authors Ocampo and Ambrosio de Morales put tremendous effort into establishing the Roman foundation under the early modern Spanish monarchy. Unlike his predecessor Ocampo, Morales got rid of the traditional scheme of universal history where the history of Spain was located within the Biblical and Christian frame of reference, created by Eusebius and Orosius, and firmly placed it within the context of Roman Empire's history (OSTENFELD-SUSKE 2012, p. 440). The 
Mediterranean countries thus produced historians who followed the Humanists' approach to the maximum. This was a representation of the so-called "raison d'État chrétienne" that came to formed in the southern regions of Europe as a response to the perceived or imagined challenges (SCHAUB 2005, p. 58- 59). It is under this pressure from the Empire that relied on its Roman tradition that in the North of Europe, in France, scholars had to invent ways to integrate their country's past into the Roman myth and at the same time prove an independent path of development. While the kingdoms of the Iberian peninsula could boast a Roman past which had significantly influenced their history, France's historians had to do with a continuous history of conflicting integration with and attempts to separate from the Empire in the form of Gallic Empire, bacaudae, multiple usurpers and general disintegration of Roman authority in Gaul at the expense of local, provincial power structures (DRINKWATER 1992; VAN DAM 1992; MACGEORGE 2002).

The situation of contact and conflict between Roman generals and civil officials, on the one hand, and barbarian chieftains, on the other, early became a theme for early modern historians. In the context of Roman Gaul rulers like Childeric (d. 481/482). and Clovis (482-511). thus become key figures whose reigns attracted much attention from early modern scholars because it was them who laid the foundations of early medieval and medieval Frankish kingdom and France. Childeric, as is now known, was a barbarian chieftain who, much like Arbogast, Odoacer, Theodoric the Great and others, managed to establish both a strong position among the Franks and at the same time to be accepted by Gallo-Romans and Roman imperial elites as a person worthy of rule in a Roman province (FRYE 1992). Gregory of Tours told how Childeric was exiled by the Franks in Soissons for his lewd behaviour and had to hide at Thuringian king Basin's household. The Franks chose instead as their ruler and even «king» a Roman general Aegidius. But according to Gregory of Tours, they soon got tired of his oppressive behaviour and called back Childeric, who triumphantly returned to rule (GREGORIUS TURONENSIS 1951, 2:12). The «Soissons kingdom» under the rule of Aegidius was one the many examples of the political units created by late Roman warlords, which were the result of the synthesis of Roman and barbarian traditions within the weakening Roman Empire and after its downfall (JAMES 1988). Although as many late Antique topics, the status of these Franks is open to scrutiny, it is likely that they had something of a «foederati» status. It is quite likely that this status was a result of the special treaty which had been concluded between emperor Julian and the Franks in Gaul in 359 after the former's successful attempts to bring order to these provinces (ROUCHE 1996, p. 451).Archaeologists suggest that his tomb shows how the new trends began to appear in the Roman provinces and that his authority was more than that of a barbarian chieftain (PÉRIN 1981; PÉRIN 1987; SALAÜN 2008, p. 218). The story of Childeric's coming to power suggested an interpenetration of Romans and barbarians. The rule of Clovis (482-511), who demanded his troops to pay homage to St.Martin, St. Hilary and their respective cities of veneration Tours and Poitiers, shows how a barbarian ruler could appeal to both Gallo-Roman elites 
and Franks after the Roman Empire was gone in 476 and create a kingdom within its former borders which was built on a synthesis of Gallo-Roman provincial and Frankish barbarian traditions (BURY 1889, p. 107; WALLACE-HADRILL 1962, p. 162; GANSHOF 1966, p. 9-12; WERNER 1984, p. 286; WERNER 1988, p. 4; JAMES 1988, p. 12; DALY 1994, p. 962-964; HEINZELMANN 1994, S. 189; LEBECQ 1990; ROUCHE 1996, p. 187; MACGEORGE 2002, p. 111-137, 169176; SCHMAUDER 2003, p. 300-306; HALSALL 2010, p. 169-187; BECHER 2011; REIMITZ 2015, p. 444). Moreover, it was a story of the split between the Mediterranean and the barbarian North that took place in Gaul when this region started to turn away from the former nominal dependence on the power center in Italy, Milan and later Ravenna, and began to exhibit more interest towards independent existence as a new political landscape where the Mediterranean and the barbarian North came in close contact.

It is therefore interesting to inquire when exactly the understanding of the close interrelationship between the Empire, the diocese of Gaul and the Franks settled into historiography and the polemics it raised in the European "republic of letters". In addition to the sense of unity within this educated community (GRAFTON 2011), it began to produce factions. We argue, however, that these boundaries of these factions did not run along purely political borders and were determined less by nascent national feeling than by the traditional struggle between the scholars of the South and those of the North for the right to claim imperial legitimacy and Roman heritage. The emergence of the Frankish kingdom as the only successful legitimate heir to Rome's provinces from among various barbarian groups was exactly this topic that shows the differences in various authors' approaches to the problem of continuity between the Western Roman Empire and Gaul as its diocese and the kingdom of the Franks as both new political unit and heir to the Empire. From Gregory of Tours, whose passage spoke of Clovis acquiring both consul and augustus status, all early modern scholars knew of the Frankish claims to partaking in imperial heritage ("Igitur ab Anastasio imperatore codecillos de consolato accepit, et in basilica beati Martini tunica blattea indutus et clamide, inponens vertice diademam. Tunc ascenso equite, aurum argentumque in itinere illo, quod inter portam atrii et eclesiam civitatis est, praesentibus populis manu propria spargens, voluntate benignissima erogavit, et ab ea die tamquam consul aut augustus est vocitatus") (GREGORIUS TURONENSIS 1951, 2:38). For dating the transformations which the perception of the Franks' coming to power in the Roman province underwent one needs to examine a number of early modern treatises.

This pride of Roman heritage and offhand dismissal of barbarians, however, did not work once used in relation to the history of other European regions, mainly the kingdom of France, and in fact caused irritation among French scholars. The latter's geographical position made them incorporate into its own history, political traditions and mentality both Mediterranean, Roman and imperial traditions and those which originated in the barbarian society of the Rhine frontier. In the work of a 15th-century French scholar Robert Gaguin the history of Frankish kingdom and France reached its best- developed format 
and his compendium of medieval knowledge of the past was well-known for all those interested in the history of the Franks (GAGUIN 1504). In his treatise he followed all those sources that were available of medieval scholars, and in the case of early medieval history relied on Gregory of Tours, staying close to his text and interpretation. But he made Frankish kings sound more friendly to the Gallo-Romans than they were described by the famous early medieval historian. Interestingly, he emphasized that Childeric received fealty from the inhabitants of Angers ca. 364 ("Andegavos in fidem recepit"), while Gregory described this as an act of capure ("civitatem obtinuit") (GREGORIUS TURONENSIS 1951, 2:18; GAGUIN 1504, fol. 2). Thus the Early Middle Ages have been studied well enough in medieval and late medieval France, although with only those sources that had been available to medieval scholars before the great discoveries of the age of the erudites, and were developed into a tradition which emphasized a long- standing connection and friendship between the Franks and the Roman Empire.

Thus first attempts to look at the Frankish kingdom from a new perspective were a compromise between Bruni's republican ideal of Rome and the realities of barbarian kingdoms which only saw the Empire. Thus an Alsatian humanist Beatus Rhenanus emphasized the Germanic origin of the barbarians who settled near the boundaries of the Roman Empire and who later came within its borders. But at the same time, he made a number of interesting statements about the relationships between the Roman Empire and the barbarians that may have looked different from those that had been developed hitherto. For example, he emphasized the fact that many Roman provinces were settled by the Germanic tribes, which in his eyes meant that they were under a significant pressure from the provincial Roman population and may have adapted to the latter's traditions of power and cultural paradigms. Thus paradoxically, although a proponent of strong barbarian influence on the history of early medieval kingdoms, he was also a scholar who emphasized that in many cases the Germanic tribes went under a significant influence of the provincial traditions. The Franks for him were one of those tribes which became the most Romanized and thus to an extent lost some of their traditional Germanic freedoms. However, he further developed this dichotomy, suggesting that only by the time of the Carolingian success the Franks were able to regain their ancient freedoms. In fact, he emphasized that the Franks were much more Romanized than had been previously suggested and showed that in the terms of early modern Europe they had almost become enslaved by the Roman Empire rather than remain a free people. In the same vein, the Visigoths were a people which encountered so deep an immersion into the Mediterranean world that they in fact lost their barbarian status (BEATUS RHENANUS 2008, p. 152-154, 228). Thus one may note that in 1531 when Beatus Rhenanus wrote his interesting treatise the divide between the North and the South, between southern and northern Gaul had not yet become an important topic for scholars of history. In fact, the divide still lay along the old Roman line of the limes on Rhine and Danube, and the mentality had not yet shifted from the center-periphery way of thinking to the new North-South one. 
The concept of the cultural domination of the Roman Empire over the barbarian world and the subject role of the barbarian in history acquired a completely different perspective when viewed from the lands North of the Alps. The dichotomy of Roman and barbarian worlds and, more importantly, the feeling of their tension and conflict was much reduced even in the treatises of Italians gone North, in comparison to the more adversarial vision one may find the Leonardo Bruni's works. It was absent in the key treatise on the Frankish history written by Paolo Emilio from Verona, «De rebus gestis Francorum» (1516), which represented a new stage in the development of this topic in the new European context (EMILIO 1516; REYNOLDS 1955). Its novelty was in the fact that this vision of Frankish history was set in the new cultural and political environment which had been imbued with Humanist sensitivities and perceptions of the past. Although in this work the author from Verona used all literary skill that was available to him and his Humanist colleagues after the works of Leonardo Bruni to establish a new Renassaince standard of vision of the history of France, he never sought to use the same dichtomy of the Roman and barbarian worlds that was used by his Humanist predecessor. In fact, he was the historian who keenly emphasized that Aegidius, the Roman general who the Franks had chosen over the exiled Childeric, also had a civilian position of governor or procurator since he was able to dispense justice in addition to military expertise ("[...] Octo annos Francis iura dixit Aegidius in amicorum cohortem [...]") (EMILIO 1516, fol. $6 \mathrm{v}$ ). This meant that unlike Gregory of Tours, this early modern historian saw in this representative of Gallo-Roman elites a person who bridged the gap between the civic traditions of the late Roman Empire and the military tradition of barbarian soldiers and foederati. In a sense, he was the scholar who set a longterm tradition that is used very actively in modern historical scholarship, that of significant similarity in the means of ruling between Gallo-Roman magnates and barbarian commanders like Childeric or Clovis (WERNER 1984, p. 286; WERNER 1988, p. 4; JAMES 1988, p. 12; ROUCHE 1996, p. 187; MACGEORGE 2002, p. 111- 137, 169-176; HALSALL 2010, p. 169-187; REIMITZ 2015, p. 444). In fact, he sought to see the Franks as those who were incorporated into the Mediterranean world of the Late Roman Gaul and of Gaul after the fall of the Empire in 476. In this sense his vision was somewhat contrary to the vision that had been proposed by Leonardo Bruni because he emphasized the unity of the Roman and of the barbarian worlds instead of making stress on their tensions.

The disparaging attitude of Bruni to the barbarians reached its peak in the writing of Paolo Giovio (1483-1552). Speaking of the Galls (and one may imagine, implying the Franks, too). he obviously considered them as barbarians, as one may understand from a polemic statement of Étienne Pasquier against him: " Que Jules Cesar n'eut les Galois en opinion de Barbares, et que I'occasion de ce vint de leur ancienne police, ensemble de ce que quelques autheurs Italiens nous veulent blasonner de ce tiltre" (PASQUIER 1560, p. 6). This French historian spend a large amount of his work proving the integration of the Galls and the Franks into the Roman cultural world. Moreover, he claimed that Romans themselves saw in the germanic peoples the main threat to the Empire and 
their heirs the reason for its downfall (PASQUIER 1560, p. 29-30). He reduced the arguments about origins of peoples, and particularly the Trojan origin of the Franks, to non- historical matter by his famous citation on this as "ticklish business": "Quant a moy, je n'ose ny bonnement contreuenir a`cette opinion, ny semblablement y consentir librement: toutes-fois il me semble que de disputer de la vielle origine des nations, c'est chose fort chatouilleuse" (PASQUIER 1560, p. 37). Thus in the works of Pasquier we may see an attempt to counter the Italian scholars' disparaging remarks about the North of Europe's people. This French historian emphasized, on the other hand, how important were the Franks for the Roman Empire, to the rulers of which they consistently lent support and troops (PASQUIER 1560, p. 19). Moreover, he emphasized from the very beginning the unity of Gaul's population, in contrast to Italy's disorder ("[...] combien qu'il n'y ait aucune comparaison des partialitez et divisions d'Italie, 'a la commune union de nostre France [...]") (PASQUIER 1560, p. 6). And it was Charlemagne who picked up the imperial title and managed to put the Franks ahead of all barbarian peoples (PASQUIER 1560, p. 30). But although Pasquier's work was a first attempt of a French historian to tackle the difficult themes of the contact between Roman and barbarian civilizations, in it he did not manage to pay adequate attention to the questions of early medieval Merovingian kingdom and left both narrative history of this period and thematic analysis outside the scope of his work.

Thus the distinction between civilization and barbarian culture was less useful in France, or rather totally adversarial, because historians, who were writing on the history of the Frankish kingdom and France, had long made use of the idea of community that the Frankish kings created in addition to espousing the Roman imperial aspirations of Clovis, Pippin III, Charlemagne, Louis the Pious and some other rulers (DU HAILLAN 1570, p. 3-4). In contrast to statement of barbarism, Du Haillan hailed the dignity of the royal dynasties which, even though lacking in Roman culture in the true sense of the term, managed to master the Roman way of holding to power. In a sense, writing a history of the Frankish kingdom in the early Middle Ages required from the very beginning a careful choice of terminology which was to make due to the complex interaction of a Roman imperial structure of power, its provincial realization, local Gallo-Roman aristocrats, the friendly barbarians both within and immediately outside the Roman border who served in legions or possessed a federate or quasi-federate status. In addition, the history of the Frankish kingdom was welldeveloped in a long-standing tradition of history treatises that had received in the Middle Ages a continuous attention and reworking. Thus the questions which historians of the Frankish kingdom asked were different from those posed by Leonardo Bruni and other Italian historians. A treatise by Bernard de Girard seigneur Du Haillan on the history of the kings of France put historical studies on the new plane because it asked and sought to give an answer to the questions important for the French vision of early modern history-writing (DU HAILLAN $1576 \mathrm{~b}$ ). This work has been shown to possess a number of qualities that made it superior in terms of coverage of French medieval history to many if not all 
previous and even some subsequent works (ALLEN 1957, p. 310). Its peculiar achievements lay less in the new information, of which there was almost none, but in restructuring of the narrative of the early medieval Frankish kingdom in a way that satisfied both those who were looking for a rhetorical treatment of the historical subject and those who interested in gathering all available information on the period.

1570s were the period which, we argue, witnessed a bifurcation in the development of history writing among French scholars. This bifurcation was visible in the choice of approaches to early medieval history and to the way in which particular scholars solved for themselves the dichotomy between the Roman Empire, its tyrannical side, and the barbarians' otherness and integration. The changes took a number of forms, in the relationships to the Roman heritage and in the assessment of the first Frankish kings and their place in the history of medieval France. One may see how the attempt to write history of France by Paolo Emilio from Verona resulted in a fairly traditional pro-Roman approach, because key elements of the narrative were discussed from the standpoint of Roman history. Thus one of the Roman generals and local imperial representatives (one may say, magnates). Aegidius was envisioned by him as both military commander and a civil official, a praefectus, whose role was to judge Frankish soldiers as if they were completely Roman in status. Sticking close to the traditional sources like Gregory of Tours, Paolo Emilio stressed those events in history that made the Franks look as long-time allies of Rome and as docile friends of Roman authority as one may imagine. Although Du Haillan chose to adorn the kings as the main bearers of medieval continuity and made them look as those who helped gather the kingdom and drive away the Roman Empire and the magnates who ruled in its names in the last decades before 476, other barbarian and external groups ("Clodion, le Cheuelu, Merouee, Clouis, Charles Martel, et Charles Magne, ont gaigné piece à piece ce Royame sur les Romains, puis sur les Gots, Visigots, Bourguignons, Alans, Sarrazins et autres barbares nations, et les ont chassez de la France") (DU HAILLAN 1570, p. 4v). While the struggle against the Visigoths was a common story in histories because of the approach of Gregory of Tours to this question for the reason of the Goths Arianism, the struggle against the Romans was a point only he among his contemporaries made in his treatise. This was in a sense contrary to Pasquier, and especially to Fauchet, who sought, on the other hand, to emphasize the early kings' integration into the Mediterranean world and acceptance by them of the Roman imperial aura in whatever form it came (PASQUIER 1560, p. 37). The place of Aegidius (Gillon). changed in Claude Fauchet's treatise because in his work he was beseiged in Soissons and ever left until his death, although Paolo Emilio wrote that he ran away to the Visigoths. "Puis ayant joint ses forces à celles des Francois, apres auoir gaigné une bataille, il chassa Gilon de son Royame; et tout le reste de sa vie le contraignit demourer en la ville de Soissons, ou (comme dit Paul Emil). fuit vers les Gots, abandonné des Francois auec la mesme legiereté qu'ils l'auoient esleu: car en ce temps-là, ils estoient remarquez pour gens varibles" (FAUCHET 1579, p. 51v-52). One may take this as a sign of certain reverence towards a Roman governor who, 
in the eyes of the educated French historiographer, was also a part of Roman history. Perhaps, his running away would count as a sign of discontinuity with the Roman past, whereas the joint rule, Childeric's in Gaul in general and Aegidius in Soissons made the Frankish kingdom a true representation of the Roman power in the diocese of Gaul. Fauchet, on the other hand, continued in the vein set by Pasquier, discussing the Frankish kings as part of the larger Mediterranean world and the group which was closely connected with the Roman Empire and its traditions "Depuis, les Romains qui demeuroient en gaule vers I'Aquitaine, travaillez par les visigoths arriens, s'allierent des Francs et leur firent la guerre sous la conduite du Comte Paul" (FAUCHET 1579, p. 53).

It is, therefore, interesting to note that Du Haillan, in contrast to Gregory of Tours, suggested how Siagrius, the son of Aegidius, sought the help of the Visigoths to return to power after he was expelled himself by the returning Childeric (DU HAILLAN 1576b, p. 24). This statement is not supported by anything contained in the bishop of Tours' treatise or any information available to modern historians, and thus is a result of the free interpretation by the early modern historian. On the other hand, in the treatise of Claude Fauchet the negative role of the Visigoths and the conflict between them and the Franks was downplayed. Instead, the balance of power in Gaul came to be seen in the context of the Late Roman political situation in the Western Mediterranean. Thus unlike Bernard Du Haillan, he emphasized that both Franks and Visigoths were part of the complex power struggles between the Western and the Eastern imperial courts, between the Western imperial court and local Romanized elites, and between the Roman and local elites, on the one hand, and barbarians, on the other. For example, he thought that it were the Gallo-Roman elites in the person of Avitus (455-456). and even Byzatine emperor Marcian (450-457) (FAUCHET 1579, p. 98-100). who were behind the advances that the Visigothic king Theoderic II (453-456). managed to make. Thus for Fauchet the Visigoths, apart from becoming an agressive force, turned instead into a warrior group who acted within the context set by the local Gallo-Roman magnates and the Byzantine Empire.

The moral aspect rang a high note in the treatise of Du Haillan, where he claimed that all kings of the first "race", the Merovingians, were in their behavior were much like children, and thus period of the Frankish history could be considered childhood " Le second age qui est de ieiunesse et adolescence commance au Roy Clovis, qui fut le premier Roy Chrestien, et qui accreust le Royame de la soy Chrestiéne ... L'age de ces Rois de la race de Clovis qui se laisserent couler aux voluptez, à la neantise, et à la nonchalance, se peult veritablement comparer à la ieunesse et adolescence" (DU HAILLAN 1570, p. 1v). Fauchet made Childeric significantly change his behaviour after a vision he had from a window of his new wife Basina's palace. He claimed that having seen the tribulations which expected the kingdom if were not change his ways, Childeric turned to the good side "Childeric à la facon des Roys (oubliant ce qui estoit mauuais, se resiouit de la belle et noble lignée qui deuoit fortir de luy" (FAUCHET 1579, p. 52v). Fauchet sought to emphasize continuity between the early medieval Frankish kingdom 
and medieval France, calling Clovis the first Louis the Christian. "Louis premier Chrétien" (FAUCHET 1579, p. 53). This was obviously an attempt to draw a line of succession between the Merovingians and the Capetians, in this case Louis IX the Saint. "Louis premier Chrétien" (FAUCHET 1579, p. 53). This construction of the rhetorical narrative with a strong emphasis on moral elements (which were supposed to be perceived on a very personal, internal level). well fits the suggestion of scholars discussing the general development of the Humanities in the early modern period (PÉCORA 2001, p. 79-116; HANSEN 2012, p. 159-161).

Thus the crisis of the mid-17th century, which has been so vividly described by scholars, was already anticipated by this bifurcation in the $1560 \mathrm{~s}-1570 \mathrm{~s}$, which already led to growing difference between rhetorical presentation, constructed around psychologization of narrative, and erudite knowledge. All authors heavily used the moral approach that had developed within the dominant paradigm of the "republic of letters". Thus looking at Pasquier's, Du Haillan's and Fauchet's treatises, one may notice that they have gone different ways. Pasquier sought to the best of his ability to stay within the erudite discourse for which establishment of fact, close relationship with the Roman Empire and the Franks' Roman heritage were important. In this he followed the tradition set out by both native French scholars like Robert Gaguin and by those Italians like Paolo Emilio who chose to move to France and write its history. Du Haillan, on the other hand, sought to construct his text with reverence to and in agreement with the principles of the rhetorical genre, paying attention to the narrative with definite psychological characterizations. Thus one may notice in the latter's work a trend which has been established for other humanities (STRUEVER 1970, p. 138; IANZITI 2007, p. 253-257; HANSEN 2012, p. 159-161). Fauchet, on the other hand, while paying significant attention to a moral lesson, tended to lean back to Gaguin's and Pasquier's reverence towards the Roman past and withheld all comments about expurgation of the "others" from Gaul. In a sense, this was in interesting case of development of historical thought between the two opposites and its subsequent synthesis. Thus by the 1570 s the polemic between scholars who claimed to their kingdoms, principalities or Empires the right to call themselves heirs of the Roman Empire subsided as a discourse of power, and turned into scholarly discussions.

The changes in the perception of early medieval history and the relevance of Roman heritage and Frankish-Roman record of cooperation in the context of creating the early medieval Frankish kingdom took place in the situation of considerable political changes in Europe. The idea of European unity, that had originated in the Middle Ages under the aegis of the Papacy, was the foundation of all interaction between the Empire and the kingdoms (ANDERSON 1998). The transformation of political power which manifested itself in the emergence of "composite monarchies", carrying the traits of "legal pluralism", may have been instrumental in providing the grounds for the scholarly community, "the republic of letters", to disagree significantly on the uses of the past. The heritage of early modern history- writing, set out by Leonardo Bruni and others, produced, as we have seen, significantly different results even within the community of French scholars of history, while the differences between scholars of the 
South (Italy, the Iberian peninsula). and the North (France, Empire, England). were much more pronounced. However, even these differences allowed for the polemics in France to stay within the boundaries of academic community. The divergent views on the relationship between the kingdom of France and the Mediterranean did show up in significant disagreements about historical events and their interpretation, but these disagreements, as we have seen, never took forms which could damage the long-term interest of the French crown towards the Mediterranean.

\section{Bibliography}

ALLEN, J. W. A history of political thought in the sixteenth century. London: Methuen, 1957.

ANDERSON, M. S. The origins of the modern European state system, 1494- 1618. The modern European state system. London; New York: Longman, 1998.

BEATUS RHENANUS. Rerum Germanicarum libri tres (1531): Ausgabe, Übersetzung, Studien. MUNDT, Felix (ed.). Tübingen: Niemeyer, 2008.

BRUNI, Leonardo. De bello italico versus gothos. s. I., 1441.

. History of the Florentine people. HANKINS, James (ed.). Cambridge: Harvard University Press, 2001.

DU HAILLAN, Bernard de Girard. De l'estat et succez des affaires de France: oeuure contenant les choses plus singulieres \& plus remarquables, aduenuës durant les regnes des rois de France, depuis Pharamo[n]d premier roy des Francs, Francons, ou Fra[n]çoys, iusques au roy Loys vnziesme: ensemble vne sommaire histoire des seigneurs, comtes, \& ducs d'Aniou. Paris: I'Huillier, 1570.

. L'Histoire de France. Paris: L'Huillier, 1576.

. L'histoire générale des rois de France jusqu'à Charles VII inclusivement. Paris: L'Huillier, 1576.

BECHER, Matthias. Chlodwig I: der Aufstieg der Merowinger und das Ende der antiken Welt. München: Beck, 2011.

BOUTEILLER, P. Un historien du XVI siecle: Etienne Pasquier. Bibliothèque d'Humanisme et Renaissance, v. 6, p. 357-392, 1945.

BOUWSMA, W. J. Three types of historiography in post-renaissance Italy. History and Theory, v. 4, p. 303-314, 1964-1965.

BOUWSMA, William J. A Usable Past: Essays in European Cultural History. Berkeley: The University of California Press, 1990.

BREISACH, E. Historiography: Ancient, Medieval, and Modern, Third Edition. Chicago: University of Chicago Press, 2008. 
BURY, John Bagnell. A history of the later Roman Empire from Arcadius to Irene (395 A.D. to 800 A.D.). London: Macmillan, 1889. v. 1.

CABRINI, Anna Maria. Macchiavelli's Florentine histories. In: NAJEMY, John M. (ed.). The Cambridge companion to Machiavelli. Cambridge: Cambridge University Press, 2010, p. 128-143.

COCHRANE, Eric W. Historians and historiography in the Italian Renaissance. Chicago: University of Chicago Press, 1981.

CONNELL, William J. Italian Renaissance Historical Narrative. In: RABASA, José et al. (eds.). The Oxford History of Historical Writing. 1400-1800. Oxford: Oxford University Press, 2012. v. 3, p. 347-363.

DALY, W. M. Clovis: how barbaric, how pagan? Speculum, v. 69, p. 919-664, 1994.

DRINKWATER, J. F. The Bacaudae of fifth-century Gaul. In: DRINKWATER, J. F.; ELTON, H. (eds.). Fifth-century Gaul: a crisis of identity? Cambridge: Cambridge University Press, 1992, p. 208-217.

ELliOT, J. H. A Europe of composite monarchies. Past \& Present, v. 137, p. 48-71, 1992.

EMILIO, Paolo. De rebus gestibus francorum. Paris: Lodocus Badicus, 1516.

FAUCHET, Claude. Recueil des antiquitez gauloises et francoises. Paris: Chez Iacques du Puys, 1579.

FEINGOLD, Mordechai. The humanities. In: TYACKE, Nicholas (ed.). The history of the University of Oxford: Seventeenth-century Oxford. Oxford: Oxford University Press, 1997. v. 4, p. 211-358.

FINDLEN, Paula. Historical Thought in the Renaissance. In: KRAMER, Lloyd; MAZA, Sarah (eds.). A Companion to Western Historical Thought. Malden: Blackwell, 2002, p. 99-122.

FRYE, David. Aegidius, Childeric, Odovacer and Paul. Nottingham Medieval Studies, v. 36, p. 1-14, 1992.

GAGUIN, Robert. Compendium Roberti Gaguini super Francorum gestis: ab ipso recognitum et auctum. Paris: Petit, 1504.

GANSHOF, F. Een historicus uit de VI-e eeuw: Gregorius van Tours. In: Medelingen van de Koniklijke Vlaamse Academie voor Wetenschappen, Letteren en Schone Kusten van Belgie, Klasse der Letteren, Bd. 28, Heft 5, 1966.

GRAFTON, Anthony. A sketch map of a lost continent: the republic of letters. In:

World made by words: scholarship and community in the early modern West. Cambridge: Harvard University Press, 2011, p. 9-34.

GRAFTON, Antony. What was history? The Art of History in Early Modern Europe. Cambridge: Cambridge University Press, 2007. 
GREGORIUS TURONENSIS. Libri Historiarum X. In: KRUSCH, Bruno; LEVISON, Wilhelm (eds.). MGH Scriptores Rerum Merovingicarum. Bd. 1.1: Gregorii episcopi Tvronensis Libri Historiarum X. 2. Aufl. Hannover, 1951.

GRELL, Chantal. La monarchie francaise et I'histoire en France au XVII siecle. Etat des recherches en France. In: GRELL, Chantal; PARAVICINI, Werner; VOSS, Jurgen (eds.). Les princes et I'histoire du XIV au XVIII siècle (Paris-Versailles, 13-16 mars 1996). Bonn: Bouvier, 1998, p. 535-554.

. L'histoire au service d'ambitions hégémoniques. La monarchie francaise et I'instrumentalisation du passé au XVIIe siècle. In: GRELL, Chantal; PELLISTRANDI, Benoit (eds.). Les cours d'Espagne et de France au XVIIe siècle. . Madrid: Casa de Velázquez, 2007, p. 263-308.

Références historiques et modéles politiques: images du pouvoir impérial en Europe XVIé-XVIIIé siècles. Revista de historiographía, v. 14 , n. 8, p. 4-11, 2011.

HALSALL, Guy. Cemeteries and society in Merovingian Gaul: selected studies in history and archaeology, 1992-2009. Leiden: Brill, 2010 (Brill's series on the early Middle Ages, v. 18).

HANSEN, João Adolfo. Instituicão retórica, técnica retórica, discurso. Matraga, v. 20, n. $33,2012$.

HARTOG, Francois. Anciens, modernes, sauvages. Paris: Galaade, 2005.

Regimes of historicity: presentism and experiences of time. Trans.

by Saskia BROWN. European perspectives: a series in social thought and cultural criticism. New York: Columbia University Press, 2015.

HARTOG, Francois and Gérard LENCLUD. Régimes d'historicité. In: DUTU, Alexandru; DODILLE, Nobert (eds.). L'État des lieux des sciences sociales. . Paris: Éditions L'Harmattan, 1993, p. 18-38.

HEINZELMANN, Martin. Gregor von Tours (538-594). «Zehn Bücher Geschichte»: Historiographie und Gesellschaftskonzept in 6 Jahrhundert. Darmstadt: Wissenschaftliche Buchgesellschaft, 1994.

HUPPERT, George. The idea of perfect history: historical erudition and historical philosophy in Renaissance France. Urbana: University of Illinois Press, 1970.

IANZITI, Gary. Challenging chronicles: Leonardo Bruni's History of the Florentine people. In: DALE, S.; LEWIN, A. W.; OSHEIM, D. J. (eds.). Chronicling History: Chroniclers and Historians in Medieval and Renaissance. University Park: Pennsylvania State University Press, 2007, p. 249-272.

. Writing history in Renaissance Italy: Leonardo Bruni and the uses of the past. Cambridge: Harvard University Press, 2012.

JAMES, E. Childéric, Syagrius et la disparition du royaume de Soissons. Revue archéologique de Picardie, v. 3, n. 4, p. 9-12, 1988. 
KELLEY, Donald R. Foundations of modern historical scholarship: language, law, and history in the French Renaissance. New York: Columbia University Press, 1970.

LE ROY LADURIE, Emmanuel. L'État royal de Louis XI à Henri IV, 14601610. Paris: Hachette, 1987.

LEBECQ, Stéphane. Les origines franques: Ve-IXe siècle. Nouvelle histoire de la France médiévale 1. Paris: Seuil, 1990.

MACGEORGE, Penny. Late Roman warlords. New York: Oxford University Press, 2002.

LE NAIN DE TILLEMONT, Louis-Sébastien. Histoire des empereurs et des autres princes qui ont regné durant les six premiers siecles de I'Eglise: de leurs guerres contre les juifs, des ecrivains profanes \& des personnes les plus illustres de leur temps: justifiée par les citations des auteurs originaux: avec des notes pour eclaircir les principales difficultez de l'histoire. Paris: Chez Charles Robustel ..., 1720.

LE NAIN DE TILLEMONT, Louis-Sébastien. Mémoires pour servir à I'histoire ecclésiastique des six premiers siècles, justifiez par les citations des auteurs originaux: avec une chronologie, ou l'on fait un abrégé de I'histoire ecclésiastique; \& avec des notes pour éclaircir les difficultez des faits \& de la chronologie. Paris: Charles Robustel, 1701.

94 PASQUIER, Étienne. Des recherches de la France. Paris: Jean Longis et Robert le Mâgnier, 1560.

MACK, Peter. A History of Renaissance Rhetoric: 1380-1620. Oxford: Oxford University Press, 2011.

OSTENFELD-SUSKE, Kira von. Writing official history in Spain: History and politics, c. 1474-1600. In: RABASA, José et al. (eds.). The Oxford History of Historical Writing. 1400-1800. Oxford: Oxford University Press, 2012. v. 3, p. 428-448.

PÉCORA, Alcir. Máquina de generos. Saõ Paulo: EdUSP, 2001.

PÉRIN, Patrick. À propos des publications récentes concernant le peuplement en Gaule à l'époque mérovingienne: la question francque. Archéologie Médiévale, v. 11, p. 125-145, 1981.

PÉRIN, Patrick;FEFFER, L.-C. Les Francs: Á la conquête de la Gaule. Paris: Armand Colin, 1987. t. 1.

REIMITZ, H. History, Frankish Identity and the Framing of Western Ethnicity, 550-850. Cambridge: Cambridge University Press, 2015 (Cambridge Studies in Medieval Life and Thought: Fourth Series).

REYNOLDS, Beatrice R. Latin Historiography: A Survey, 1400-1600. Studies in the Renaissance, v. 2, p. 7-66, 1955. 
ROUCHE, M. Clovis: suivi de vingt et un documents traduits et commentés. Paris: Fayard, 1996.

SALAÜN, G., A. MCGREGOR et P. PÉRIN. Empreintes inédites de l'anneau sigillaire de Childéric Ier: état des connaissances. Antiquités Nationales, 39, p. 217-224, 2008.

SCHAUB, J. La notion d'État Moderne est-elle utile? Cahiers du Monde Russe, v. 46, n. 1-2, p. 51-64, 2005.

SCHMAUDER, M. The relationship between Frankish gens and regnum: a proposal based on archaeological evidence. In: GOETZ, H.-W.; JARNUT, J.; POHL, W. (eds.). Regna and gentes: The relationship between Late Antique and early medieval peoples and kingdoms in the transformation of the Roman world. Leiden: Brill, 2003, p. 271-306 (The Transformation of the Roman World, 13).

STRUEVER, Nancy S. The language of history in the Renaissance: rhetoric and historical consciousness in Florentine humanism. Princeton: Princeton University Press, 1970.

VAN DAM, Raymond. The Pirenne thesis and fifth-century Gaul. In: Fifthcentury Gaul: A crisis of identity? DRINKWATER, J. F.; ELTON, H. (eds.). Cambridge: Cambridge University Press, 1992, p. 321-34.

VICKERS, Brian. Rhetorical and anti-Rhetorical tropes: on writing the history of elocutio. In: SCHAFFER, E. S. (ed.). Comparative criticism: a yearbook. . Cambridge: Cambridge University Press, 1981. v. 3, p. 105-132.

WALLACE-HADRILL, J. M. The long-haired kings and other studies in Frankish history. New York: Barnes \& Noble, 1962.

WERNER, Karl Ferdinand. De Childéric à Clovis: antécédents et conséquences de la bataille de Soissons en 486. Revue archéologique de Picardie, $v$. 3-4, n. 1, p. 3-7, 1988.

. Les Origines. Histoire de France 1. Paris: Librairie Arthème Fayard, 1984. 